\title{
Dose adjustment for tyrosine kinase inhibitors in non-small cell lung cancer patients with hepatic or renal function impairment (Review)
}

\author{
DEHUA ZHAO, JING CHEN, XIAOQING LONG and JISHENG WANG \\ Department of Clinical Pharmacy, The Third Hospital of Mianyang (Sichuan Mental Health Center), \\ Mianyang, Sichuan 621000, P.R. China
}

Received May 29, 2020; Accepted October 27, 2020

DOI: $10.3892 /$ or.2020.7870

\begin{abstract}
In recent years, a number of tyrosine kinase inhibitors (TKIs) have been approved for the treatment of non-small cell lung cancer. These novel treatments exhibit improved efficacy and toxicity when compared to conventional chemotherapy agents. TKIs are administered orally, which has the advantages of improved flexibility and convenience for the patients. However, challenges have arisen in the use of these novel agents. Prescribing drugs for patients with hepatic or renal function impairment poses a challenge for clinicians due to the large pharmacokinetic variability in each individual patient. Moreover, several TKIs have been shown to cause laboratory test abnormalities normally associated with hepatic or renal injury. The aim of the present review was to discuss the effects of hepatic and renal function impairment on the pharmacokinetic variability of 17 TKIs and their potential hepatotoxicity and nephrotoxicity, and to recommend dose adjustment for patients with hepatic or renal impairment.
\end{abstract}

\section{Contents}

1. Introduction

2. TKIs approved for the treatment of NSCLC

3. Dose adjustment for patients with HI

4. Dose adjustment for patients with RI

5. Potential, hepatotoxicity and nephrotoxicity of TKIs

6. Discussion

7. Conclusion

Correspondence to: Dr Jisheng Wang, Department of Clinical Pharmacy, The Third Hospital of Mianyang (Sichuan Mental Health Center), 190 Jiannan Dong, Mianyang, Sichuan 621000, P.R. China E-mail: wangjishengyaoshi@163.com

Key words: tyrosine kinase inhibitors, non-small cell lung cancer, renal impairment, hepatic impairment, dose adjustment

\section{Introduction}

Lung cancer remains the leading cause of cancer-related mortality, and non-small-cell lung cancer (NSCLC) represents $\sim 85 \%$ of all cases (1). NSCLC has been shown to be driven by various activated oncogenes, such as epidermal growth factor receptor (EGFR) and anaplastic lymphoma kinase (ALK) (2-4). The identification of genetic driver alterations in patients with NSCLC and the use of effective targeted agents have been recommended by the National Comprehensive Cancer Network and European Society for Medical Oncology guidelines, offering new promising strategies for patients with NSCLC $(5,6)$. To date, a number of small-molecule targeted drugs have been developed for the treatment of NSCLC, most of which are tyrosine kinase inhibitors (TKIs). Compared with traditional chemotherapy drugs, TKIs are associated with significantly improved clinical outcomes and reduced treatment-associated toxicity (7). As TKIs are given orally at a fixed dose for long periods of time, they represent an easy and convenient drug regimen for patients with cancer. However, administration of TKIs is also associated with certain risks, such as a large variability in pharmacokinetics (PK), particularly in patients with concurrent hepatic impairment (HI) or renal impairment $(\mathrm{RI})(8,9)$.

$\mathrm{HI}$ and RI are common in patients with cancer, and they are intrinsic factors that may affect the absorption, distribution, metabolism and excretion of orally administered drugs $(8,9)$. As a result of the alterations in drug PK, effective drug exposure may increase or decrease, leading to suboptimal efficacy or substantial toxicity. In addition, certain TKIs may induce hepatic or renal toxicities. Thus, understanding the effects of HI and RI on PK variability of specific anticancer drugs and their potential hepatotoxicity and nephrotoxicity is crucial for selecting the appropriate doses and dosing intervals, thus insuring maximum efficacy and minimal toxicity. The aim of the present review was to summarize the potential hepatotoxicity and nephrotoxicity of 17 TKIs and their PK variability in patients with HI or RI. Furthermore, based on available evidence from drug labels and published literature, dose recommendations for the 17 TKIs are provided for NSCLC patients with varying degrees of $\mathrm{HI}$ or RI. 


\section{TKIs approved for the treatment of NSCLC}

As mentioned above, the identification of genetic driver alterations has created new therapeutic interventions for patients with NSCLC $(5,6)$. Driver mutations identified in NSCLC include EGFR mutations, ALK rearrangement, c-ros oncogene $\left(\mathrm{ROS}_{1}\right)$ rearrangement, B-RAF proto-oncogene (BRAF) V600E mutations, neurotrophin tyrosine receptor kinase gene fusions, high-level MET amplification or MET exon 14 skipping mutations, and RET rearrangements (5). As a number of the identified driver mutations activate tyrosine kinase signaling pathways, strategies to inhibit these pathways by TKIs have been developed and approved for the treatment of NSCLC (10-56). The TKIs approved for the treatment of patients with NSCLC and their PK properties are listed in Table I.

\section{Dose adjustment for patients with HI}

The liver is involved in the absorption, distribution and elimination of most drugs and their metabolites (8). HI does not only affect the hepatic metabolism or biliary excretion, but may also affect protein binding (PB), intestinal enzymes and transporters, which may ultimately affect drug absorption and distribution $(8,57,58)$. The effect of $\mathrm{HI}$ on the absorption of orally administered drugs is mainly the result of a reduced first-pass effect, leading to an increased bioavailability of oral drugs in patients with HI (59). Similarly, HI may increase the distribution of many drugs by decreasing the PB. Mechanisms underlying the decreased binding of drugs to plasma proteins include low levels of plasma proteins, accumulation of endogenous substances [e.g., bilirubin (Bil)], and qualitative changes in plasma proteins (60). As most drugs are metabolized by the liver, impaired hepatic function may decrease their metabolism by reducing the levels and activity of hepatic enzymes and transporters and, consequently, alter the exposure to drugs and their metabolites (61). In addition to decreased metabolizing capacity and decreased PB, reduced biliary excretion may also occur in patients with HI (62). Moreover, HI may also affect kidney function, leading to an accumulation of a drug and its metabolites, even when the liver is not primarily responsible for their elimination (63).

The extent of alterations in PK is associated with the degree of HI (58). The US Food and Drug Administration (FDA) and European Medicines Agency (EMA) recommend using the Child-Pugh (C-P) classification to categorize the degree of HI $(64,65)$. However, studies have often used other grading systems to assess liver function (66), and the results from these different grading systems are not interchangeable and, hence, are difficult to compare with one another. Therefore, multiple $\mathrm{HI}$ descriptions are presented in our dose recommendations. The classification of HI by C-P score and National Cancer Institute (NCI) criteria are listed in Table II.

Taking the aforementioned points into account, HI may increase the bioavailability and distribution of orally administered drugs, reduce metabolizing capacity, biliary and renal excretion, consequently increasing the drug exposure $(8,58)$. Therefore, dose adjustment should be considered in patients with HI. The dose adjustment recommendations for TKIs in NSCLC patients with HI are summarized in Table III.
Afatinib. Afatinib is metabolized only to a minor extent ( 9\%) and, in the circulation, forms covalent adducts with plasma proteins. Excretion of afatinib is primarily via the feces $(10,11)$. As shown in PK studies, exposure to afatinib was not significantly altered in patients with C-P A and B; therefore, dose adjustment in this population is not deemed necessary $(10,11)$. Subjects with C-P C have not been studied; therefore, the recommendation is to use afatinib with caution or not at all in this patient population $(10,11)$.

Alectinib. Alectinib is eliminated primarily by the liver $(12,13)$. In a clinical study, the combined area under the plasma drug concentration-time curve (AUC) of alectinib and its major metabolite (M4) increased by 36 and $76 \%$ in subjects with C-P B and C, respectively (14). The combined $\mathrm{C}_{\max }$ of alectinib and M4 increased by $16 \%$ in patients with C-P B and decreased by $2 \%$ in patients with C-P C (14). Therefore, dose adjustment is not necessary for patients with C-P A and $\mathrm{B}$, but is necessary for patients with CP-C. In these patients, the dose should be reduced to $450 \mathrm{mg}$ twice daily (12-14).

Brigatinib. Brigatinib is eliminated primarily via the liver $(15,16)$. The brigatinib AUC was by $37 \%$ higher in subjects with C-P C compared to subjects with normal hepatic function (NHF), while subjects with C-P A and B had a similar brigatinib AUC compared to subjects with $\operatorname{NHF}(15,16)$. Based on these data, dose adjustment is not required for patients with C-P A and B $(15,16)$, whereas the dose should be reduced by $\sim 40 \%$ (i.e., from 180 to $120 \mathrm{mg}$, or from 90 to $60 \mathrm{mg}$ ) in patients with C-P C (16).

Cabozantinib. Based on a population PK analysis, no clinically significant differences in cabozantinib exposure were observed between subjects with mild HI (based on the NCI criteria) and those with NHF (20). In a HI study, the cabozantinib AUC and $\mathrm{C}_{\max }$ increased by 81 and $10 \%$, respectively, in subjects with C-P A (21); for subjects with C-P B, the cabozantinib AUC increased by $63 \%$ and $C_{\max }$ decreased by $29 \%$ (21). As cabozantinib exposure was significantly altered in C-P A and $\mathrm{B}$, dose reduction is necessary for these patients (17-21). Cabozantinib is not recommended for use in patients with C-P C, since the safety and efficacy have not been characterized in this population $(17,18)$.

Ceritinib. Ceritinib is primarily eliminated by the liver $(22,23)$. A clinical study was conducted to evaluate the effect of HI on ceritinib PK. The AUC of ceritinib was increased by 18,2 and $66 \%$ in subjects with C-P A, B and C, respectively, compared with subjects with NHF $(22,23)$. Based on these data, dose adjustment is not required for patients with C-P A and $\mathrm{B}$, but the ceritinib dose should be reduced by approximately one-third in patients with C-P C $(22,23)$.

Crizotinib. Crizotinib is eliminated primarily by the liver $(24,25)$. Following oral crizotinib administration at doses of $250 \mathrm{mg}$ twice daily, patients with mild HI (based on the NCI criteria) exhibited similar crizotinib exposure at steady state compared to patients with NHF, with AUC and $\mathrm{C}_{\max }$ decreasing by $9 \%$ (26). Therefore, dose adjustment is not required for patients with mild HI (24-26). Patients with moderate HI 


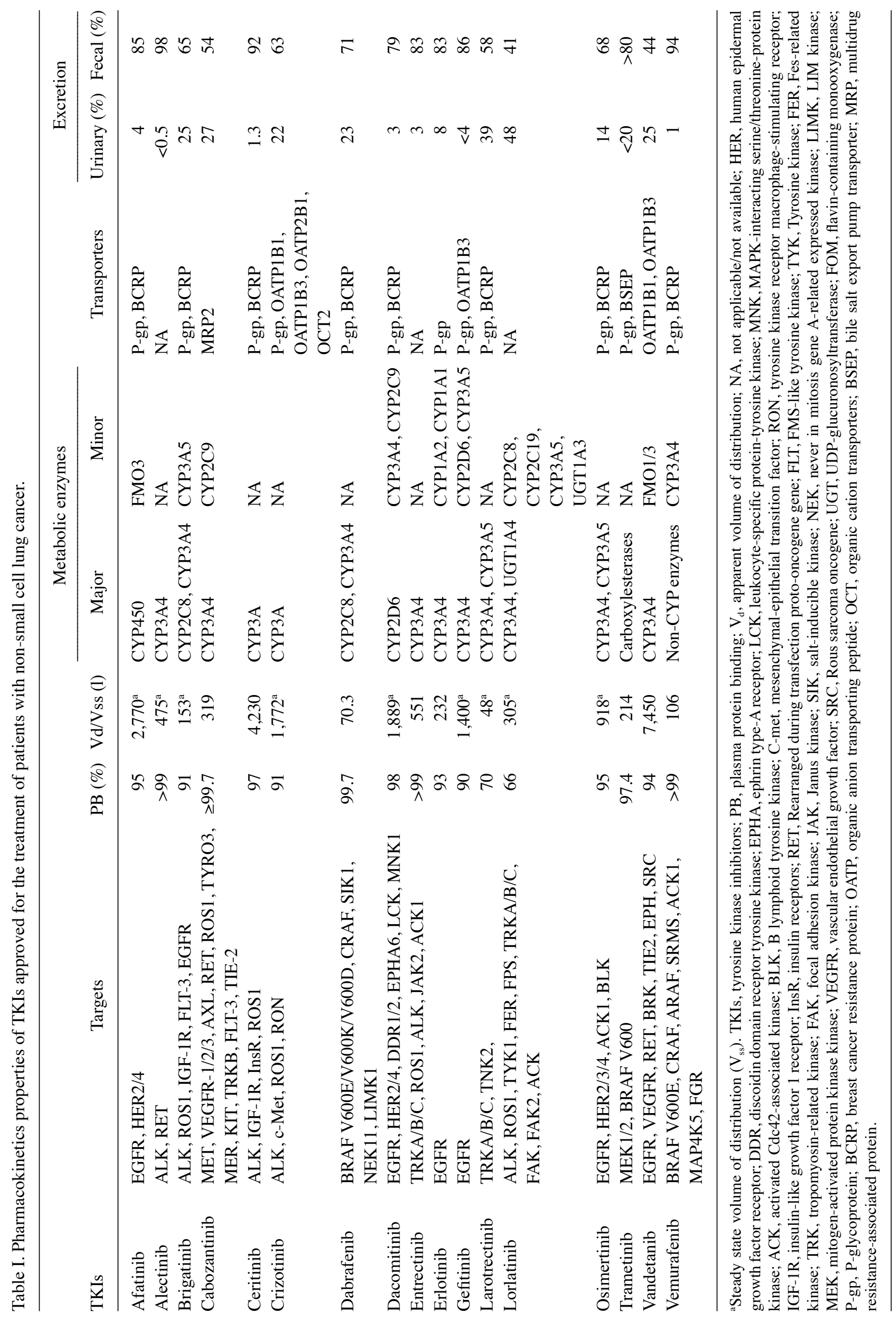


Table II. Classification of hepatic impairment by Child-Pugh score and NCI.

\begin{tabular}{lll}
\hline Degree & Child-Pugh classification (points) & \multicolumn{1}{c}{ NCI classification } \\
\hline Mild & A $(5-6)$ & TBil $\leq$ ULN and AST $>$ ULN, or TBil $>1-1.5 x$ ULN and any AST \\
Moderate & B (7-9) & TBil $>1.53 x$ ULN and any AST \\
Severe & C (10-15) & TBil $>3$ 10x ULN and any AST \\
\hline
\end{tabular}

NCI, National Cancer Institute; TBil, total bilirubin; AST, aspartate aminotransferase; ULN, upper limit of normal.

exhibited higher crizotinib exposure compared to patients with NHF, with AUC and $\mathrm{C}_{\max }$ increasing by 50 and $44 \%$, respectively (26). The crizotinib AUC decreased by $35 \%$ and $\mathrm{C}_{\max }$ decreased by $27 \%$ in patients with severe HI following crizotinib $250 \mathrm{mg}$ orally once daily compared with patients with NHF following crizotinib $250 \mathrm{mg}$ orally twice daily (26). Based on these results, crizotinib $200 \mathrm{mg}$ twice daily is recommended for patients with moderate $\mathrm{HI}$, and $250 \mathrm{mg}$ once daily for patients with severe HI (24-26).

Dabrafenib. Based on a population PK analysis, the effect of mild HI (based on the NCI criteria) on the concentration of dabrafenib or its metabolites was not significant (29). Therefore, dose adjustment is not required for patients with mild HI (27-29). No data are available for patients with moderate to severe HI. However, considering that dabrafenib is mainly eliminated by the liver, patients with moderate to severe HI should be treated with caution (28).

Dacomitinib. Dacomitinib is eliminated primarily by the liver $(30,31)$. In a dedicated $\mathrm{HI}$ trial, the AUC and $\mathrm{C}_{\max }$ of dacomitinib were unchanged in subjects with C-P A, whereas they decreased by 15 and $20 \%$, respectively, in subjects with C-P B, as compared to subjects with NHF (32). Based on this trial, C-P A and B exerted no clinically important effects on the PK of dacomitinib. In addition, based on a population PK analysis, dose adjustment is not required for patients with mild and moderate HI (according to the NCI criteria) $(30,31)$. The effect of severe HI (both NCI and C-P criteria) on dacomitinib $\mathrm{PK}$ is unknown, and treatment in this patient population is not recommended (31).

Entrectinib. Entrectinib is eliminated primarily via the liver (33). In a population PK analysis, no clinically significant differences in the PK of entrectinib were observed in patients with mild HI (based on the NCI criteria) compared with subjects with NHF (33). Therefore, dose adjustment is not required in this patient population (33). The impact of moderate to severe $\mathrm{HI}$ on the PK of entrectinib is unknown; therefore, there are currently no dose recommendations for these populations.

Erlotinib. Erlotinib is primarily eliminated by the liver $(34,35)$. The PK and safety profiles of erlotinib in patients with C-P B were found to be similar to those with NHF; therefore, dose adjustment is not required for patients with C-P B (36). No data are available regarding the effect of C-P C on the PK of erlotinib; therefore, erlotinib must be used with caution, or not at all, in patients with CP-C $(34,35)$. In a phase I study, the erlotinib clearance was reduced and dose-limiting toxicities were increased in patients with $\mathrm{HI}$ [aspartate aminotransferase $\geq 3 \mathrm{x}$ upper limit of normal (ULN), or direct Bil $>17 \mu \mathrm{mol} / \mathrm{l}]$ (37). Therefore, a $50 \%$ dose reduction was recommended for patients with this level of HI (37).

Gefitinib. Gefitinib is cleared primarily by the liver $(38,39)$. In a study of non-cancer patients with HI due to cirrhosis, the exposure to gefitinib was increased by 40,263 and $166 \%$ in patients with $\mathrm{C}-\mathrm{P} \mathrm{A}, \mathrm{B}$ and $\mathrm{C}$, respectively, compared to healthy subjects (40). However, the PK of gefitinib is highly variable in subjects with $\mathrm{HI}$ due to cirrhosis and, considering the low dose reduction rate observed when gefitinib was administered at a dose 2-fold higher than the recommended dose, no dose adjustment was recommended in patients with HI due to cirrhosis (38-40). In case of patients with cancer, the exposure of gefitinib was similar between patients with moderate and severe HI (according to the NCI criteria) when compared to patients with NHF (40). Based on these results, dose adjustment may not be necessary for patients with $\mathrm{HI}$; however, considering its hepatotoxicity, close monitoring is required for patients with $\mathrm{C}-\mathrm{P} \mathrm{B}$ and $\mathrm{C}$ due to liver metastases (38-40).

Larotrectinib. Larotrectinib is eliminated primarily via the liver $(41,42)$. In a PK study, the larotrectinib AUC increased by 30,100 and $220 \%$, and $C_{\max }$ increased by 10,10 and $50 \%$ in patients with C-P A, B and C, respectively, when compared to subjects with NHF $(41,42)$. Therefore, dose adjustment is not required for patients with C-P A, but the starting dose of larotrectinib should be reduced by $50 \%$ in patients with C-P B and $\mathrm{C}(41,42)$.

Lorlatinib. Lorlatinib is primarily metabolized in the liver and excreted in both the urine $(48 \%)$ and feces $(41 \%)(43,44)$. Based on a population $\mathrm{PK}$ analysis, no clinically meaningful differences in lorlatinib PK were observed in patients with mild HI (based on the NCI criteria) (43). Therefore, dose adjustment is not required in patients with mild HI $(43,44)$. The effect of moderate to severe HI on lorlatinib PK is unknown; therefore, lorlatinib is not recommended for use in these patients (44).

Osimertinib. Osimertinib is eliminated primarily via the liver $(45,46)$. In a clinical trial, the osimertinib AUC and $\mathrm{C}_{\max }$ decreased by 36.7 and $48.6 \%$, respectively, in patients with C-P A, and by 31.6 and $39.3 \%$, respectively, in patients with C-P B, when compared to patients with NHF (47). In terms of 


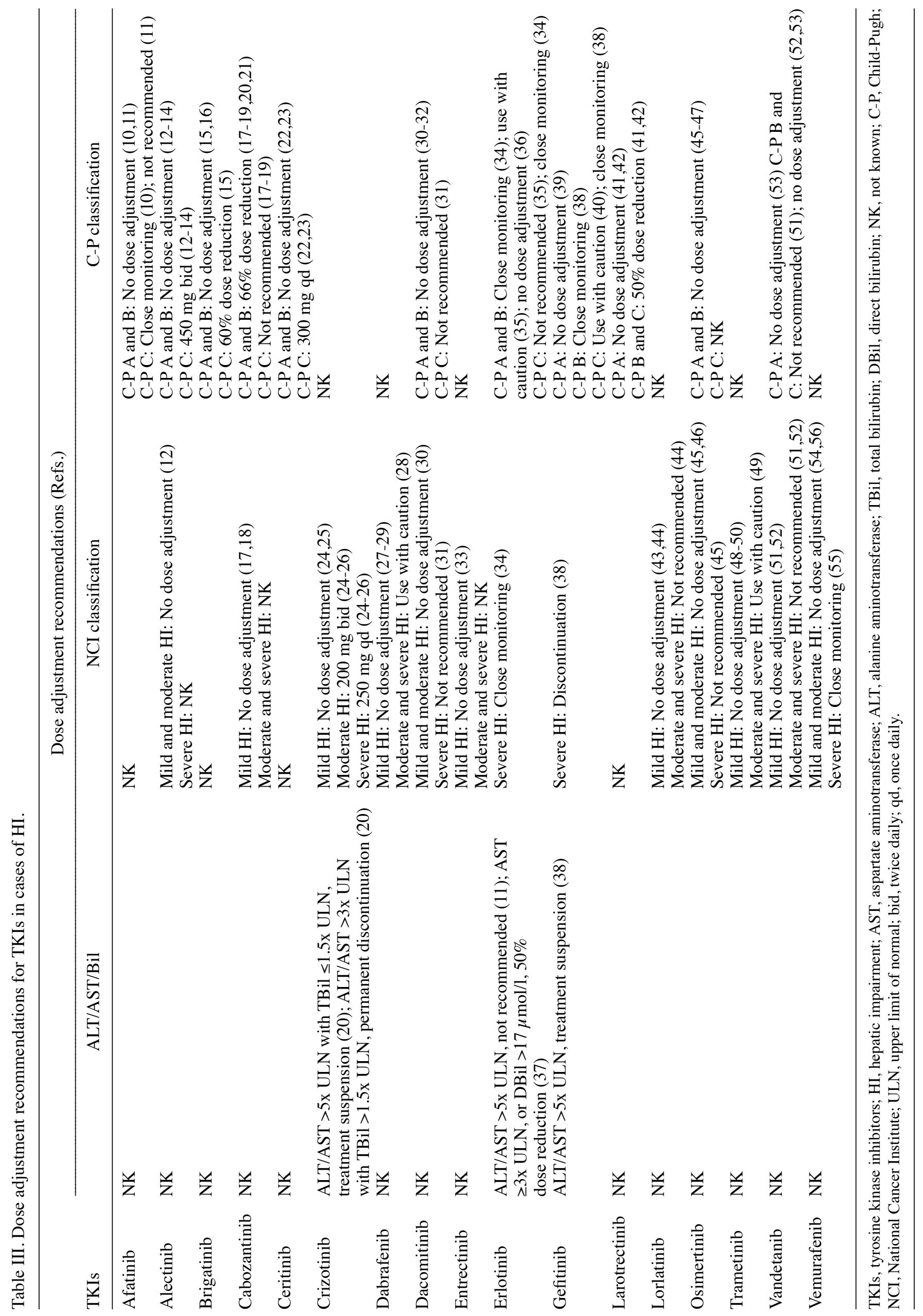


safety, there were no apparent differences in safety between patients with NHF and those with C-P A or B (47). In a population PK analysis, the PK of osimertinib exhibited no clinically significant differences in patients with mild or moderate HI (according to the NCI criteria), compared to patients with NHF $(45,46)$. Therefore, based on the population PK analysis and clinical study results, dose adjustment is not necessary for patients with mild and moderate HI (both NCI and C-P criteria) (45-47). Since no study has been conducted in patients with severe HI, osimertinib is not recommended for use in this population (46).

Trametinib. Trametinib is eliminated primarily via the liver $(48,49)$. Formal clinical studies have not been conducted to assess the effect of organ impairment on the PK of trametinib. A population PK analysis demonstrated that mild HI did not affect the PK of trametinib (50); therefore, dose adjustment is not required for this patient population (48-50). The PK of trametinib has not been investigated in patients with moderate to severe $\mathrm{HI}$; therefore, trametinib should be administered with caution in this patient population (49).

Vandetanib. A PK study demonstrated that the vandetanib AUC increased by $4 \%$ in patients with C-P A and decreased by 6 and $7 \%$ in patients with C-P B and C, respectively, compared to patients with NHF (53). Given that exposure to vandetanib was not altered in subjects with HI, no dose adjustment appears to be necessary in patients with C-P A, B and C (51-53).

Vemurafenib. Vemurafenib is eliminated primarily via the liver $(54,55)$. In clinical trials, the apparent clearance of vemurafenib was similar between patients with mild to moderate HI (based on the NCI criteria) and those with NHF, indicating that dose adjustment is not required for patients with mild to moderate HI $(54,56)$. As few patients with severe HI were enrolled in clinical trials, close monitoring is required when vemurafenib is administered to patients with severe HI (55).

\section{Dose adjustment for patients with RI}

The kidney and the liver are the two main organs responsible for the elimination of drugs. Impaired renal function may decrease the excretion of a drug or its metabolites that are primarily or partly eliminated via the kidneys $(9,58)$. In addition, RI may also affect the non-renal disposition of drugs that are eliminated by the liver via alterations in the expression and activity of drug-metabolizing enzymes and transporters in the liver $(67,68)$. Although the most obvious changes with RI affect the elimination of drugs as well as their metabolites, RI may also be associated with other changes, such as absorption and PB (9). Alterations in drug absorption in patients with RI may result from delayed gastric emptying, changes in gut motility, changes in gastric $\mathrm{pH}$, decrease in first-pass effect, and vomiting or diarrhea (69). Alterations in PB are a result of hypoalbuminemia and accumulation of endogenous substances (e.g., uremic toxins) (69).

The extent of PK alterations depends on the degree of RI $(9,58)$. For example, the AUC of afatinib increased by 22 and $50 \%$ in patients with moderate and severe RI, respectively, when compared to patients with normal renal function (NRF) (70). There are several methods currently used to categorize the degree of RI in patients, among which estimated glomerular filtration rate (eGFR) is the most commonly used in clinical practice and has been included in the FDA and EMA guidelines (71). Therefore, eGFR is used as a measure of renal function in order to make dose recommendations.

In conclusion, RI not only affects the PK of renally eliminated drugs, but may also affect drugs not eliminated by the kidneys $(58,67)$. If a drug's PK is significant altered in patients with RI, a dose adjustment is required to ensure its efficacy and safety. TKIs are considered safer than chemotherapy drugs, but may still cause serious side effects when their systemic concentrations and exposure are increased (72). Therefore, dose adjustments are required for certain TKIs in patients with RI. The dose adjustment recommendations for TKIs in NSCLC patients with RI are summarized in Table IV.

Afatinib. Compared with patients with NRF, the afatinib AUC and $\mathrm{C}_{\max }$ increased by 50 and $22 \%$, respectively, in subjects with severe RI and increased by 22 and $1 \%$, respectively, in subjects with moderate RI (70). Based on these results, dose adjustment is not required for patients with mild to moderate RI, but a $25 \%$ dose reduction is recommended for patients with severe RI $(10,11,70)$. In case reports, afatinib at a dose of $30 \mathrm{mg}$ once daily was tolerated and effective for patients with end-stage renal disease (ESRD) undergoing hemodialysis (HD) $(73,74)$.

Alectinib. From a patient population PK analysis, mild to moderate RI exerted no clinically meaningful effect on the exposure of alectinib and its major metabolite (M4), suggesting that dose adjustment is not required in patients with mild to moderate RI $(12,13)$. The PK of alectinib have not been studied in patients with severe RI, but a case report demonstrated that a patient with ESRD undergoing HD was safely treated with alectinib at a dose of $600 \mathrm{mg}$ daily. The patient exhibited no disease progression for 34 months (75).

Brigatinib. The brigatinib AUC was $86 \%$ higher in subjects with severe RI compared to subjects with NRF $(15,16)$. Based on a population PK analysis, the PK of brigatinib was similar between patients with NRF and those with mild to moderate RI $(15,16)$. Thus, dose adjustment is not required for patients with mild to moderate RI, but the dose should be reduced by $\sim 50 \%$ in patients with severe RI (15).

Cabozantinib. Results from a study in patients with RI indicated that the cabozantinib AUC and $\mathrm{C}_{\max }$ were 30 and $19 \%$ higher, respectively, for subjects with mild RI, and 2 and $6 \%$ higher, respectively, for subjects with moderate RI compared to subjects with NRF (21). Based on the small exposure increase with mild to moderate RI, dose adjustment is not required for patients with mild to moderate RI (17-21). Since patients with severe RI have not been studied, cabozantinib is not recommended for use in this patient population (19).

Ceritinib. Based on patient population PK analysis, the ceritinib AUC in patients with mild to moderate RI was predicted to increase by 9 and $19 \%$, respectively, compared to patients with NRF (76). These differences are not considered to be clinically relevant; hence, dose adjustment is not deemed necessary in patients with mild to moderate RI $(22,23,76)$. 
Table IV. Dose adjustment recommendations for TKIs in cases of renal impairment.

Dose adjustment recommendations (Refs.)

\begin{tabular}{|c|c|c|c|c|c|}
\hline \multirow[b]{2}{*}{ TKIs } & \multirow[b]{2}{*}{ Mild impairment $^{\mathrm{a}}$} & \multirow[b]{2}{*}{ Moderate impairment ${ }^{\mathrm{b}}$} & \multirow[b]{2}{*}{ Severe impairment ${ }^{c}$} & \multicolumn{2}{|c|}{ ESRD $^{d}$} \\
\hline & & & & Not on HD & Requiring HD \\
\hline Afatinib & $\begin{array}{l}\text { No dose adjustment } \\
(10,11)\end{array}$ & $\begin{array}{l}\text { No dose adjustment } \\
(10,11,70)\end{array}$ & 30 mg qd (10) & $\begin{array}{l}\text { Not recommended } \\
\text { (11) }\end{array}$ & $30 \mathrm{mg}$ qd $(73,74)$ \\
\hline Alectinib & $\begin{array}{l}\text { No dose adjustment } \\
(12,13)\end{array}$ & $\begin{array}{l}\text { No dose adjustment } \\
(12,13)\end{array}$ & $\begin{array}{l}\text { Withhold (12) No } \\
\text { dose adjustment (13) }\end{array}$ & $\begin{array}{l}\text { Treatment } \\
\text { suspension (12) }\end{array}$ & $\begin{array}{l}50 \% \text { dose } \\
\text { reduction }(75)\end{array}$ \\
\hline Brigatinib & $\begin{array}{l}\text { No dose adjustment } \\
(15,16)\end{array}$ & $\begin{array}{l}\text { No dose adjustment } \\
(15,16)\end{array}$ & $\begin{array}{l}50 \% \text { dose reduction } \\
\text { (15) }\end{array}$ & NK & NK \\
\hline Cabozantinib & $\begin{array}{l}\text { No dose adjustment } \\
(17,18,21) \text { Use with } \\
\text { caution (19) }\end{array}$ & $\begin{array}{l}\text { No dose adjustment } \\
(17,18,21) \text { Use with } \\
\text { caution }(19)\end{array}$ & $\begin{array}{l}\text { Not recommended } \\
\text { (19) }\end{array}$ & $\begin{array}{l}\text { Not recommended } \\
\text { (19) }\end{array}$ & NK \\
\hline Ceritinib & $\begin{array}{l}\text { No dose adjustment } \\
(22,23,76)\end{array}$ & $\begin{array}{l}\text { No dose adjustment } \\
(22,23,76)\end{array}$ & $\begin{array}{l}\text { Use with caution } \\
\text { (23) }\end{array}$ & $\begin{array}{l}\text { Use with caution } \\
\text { (23) }\end{array}$ & NK \\
\hline Crizotinib & $\begin{array}{l}\text { No dose adjustment } \\
(24,25,77,78)\end{array}$ & $\begin{array}{l}\text { No dose adjustment } \\
(24,25,77,78)\end{array}$ & $250 \mathrm{mg}$ qd $(24,25)$ & 250 mg qd (79) & 250 mg qd (80) \\
\hline Dabrafenib & $\begin{array}{l}\text { No dose adjustment } \\
(27-29)\end{array}$ & $\begin{array}{l}\text { No dose adjustment } \\
(27-29)\end{array}$ & $\begin{array}{l}\text { Use with caution } \\
\text { (28) }\end{array}$ & $\begin{array}{l}\text { Use with caution } \\
\text { (28) }\end{array}$ & 75 mg qd (81) \\
\hline Dacomitinib & $\begin{array}{l}\text { No dose adjustment } \\
(30,31)\end{array}$ & $\begin{array}{l}\text { No dose adjustment } \\
(30,31)\end{array}$ & NK & NK & NK \\
\hline Entrectinib & $\begin{array}{l}\text { No dose adjustment } \\
\text { (33) }\end{array}$ & No dose adjustment (33) & NK & NK & NK \\
\hline Erlotinib & $\begin{array}{l}\text { No dose adjustment } \\
\text { (35) }\end{array}$ & No dose adjustment (35) & $\begin{array}{l}\text { Not recommended } \\
\text { (35) No dose } \\
\text { adjustment (37) }\end{array}$ & $\begin{array}{l}\text { Not recommended } \\
\text { (35) }\end{array}$ & $\begin{array}{l}\text { No dose } \\
\text { adjustment } \\
(82,83)\end{array}$ \\
\hline Gefitinib & $\begin{array}{l}\text { No dose adjustment } \\
\text { (39) }\end{array}$ & No dose adjustment (39) & $\begin{array}{l}\text { eGFR }>20 \mathrm{ml} / \mathrm{min} \text {, } \\
\text { no dose adjustment; } \\
\leq 20 \mathrm{ml} / \mathrm{min} \text {, use with } \\
\text { caution (39) }\end{array}$ & $\begin{array}{l}\text { Use with caution } \\
\text { (15) No dose } \\
\text { adjustment (84) }\end{array}$ & $\begin{array}{l}\text { No dose } \\
\text { adjustment } \\
(85-88)\end{array}$ \\
\hline Larotrectinib & $\begin{array}{l}\text { No dose adjustment } \\
(41,42)\end{array}$ & $\begin{array}{l}\text { No dose adjustment } \\
(41,42)\end{array}$ & $\begin{array}{l}\text { No dose adjustment } \\
(41,42)\end{array}$ & $\begin{array}{l}\text { No dose } \\
\text { adjustment }(41,42)\end{array}$ & $\begin{array}{l}\text { No dose } \\
\text { adjustment } \\
(41,42)\end{array}$ \\
\hline Lorlatinib & $\begin{array}{l}\text { No dose adjustment } \\
(43,44)\end{array}$ & $\begin{array}{l}\text { No dose adjustment } \\
(43,44)\end{array}$ & $\begin{array}{l}\text { Not recommended } \\
\text { (44) }\end{array}$ & $\begin{array}{l}\text { Not recommended } \\
\text { (44) }\end{array}$ & NK \\
\hline Osimertinib & $\begin{array}{l}\text { No dose adjustment } \\
(45,46)\end{array}$ & $\begin{array}{l}\text { No dose adjustment } \\
(45,46)\end{array}$ & $\begin{array}{l}\text { Use with caution (46) } \\
\text { No dose adjustment } \\
\text { (89) }\end{array}$ & $\begin{array}{l}\text { Use with caution } \\
\text { (46) }\end{array}$ & $\begin{array}{l}\text { No dose } \\
\text { adjustment } \\
(90-92)\end{array}$ \\
\hline Trametinib & $\begin{array}{l}\text { No dose adjustment } \\
(48-50)\end{array}$ & $\begin{array}{l}\text { No dose adjustment } \\
(48-50)\end{array}$ & Use with caution (49) & $\begin{array}{l}\text { Use with caution } \\
\text { (49) }\end{array}$ & $0.5 \mathrm{mg} \mathrm{qd}(81)$ \\
\hline Vandetanib & $\begin{array}{l}\text { No dose adjustment } \\
(51-53)\end{array}$ & $\begin{array}{l}200 \text { mg qd (51) Not } \\
\text { recommended (52) }\end{array}$ & $\begin{array}{l}200 \text { mg qd (51) Not } \\
\text { recommended (52) }\end{array}$ & $\begin{array}{l}200 \mathrm{mg} \mathrm{qd}(51) \\
\text { Not recommended } \\
(52)\end{array}$ & NK \\
\hline Vemurafenib & $\begin{array}{l}\text { No dose adjustment } \\
(54-56)\end{array}$ & $\begin{array}{l}\text { No dose adjustment } \\
(54-56)\end{array}$ & $\begin{array}{l}\text { Close monitoring } \\
\text { (55) }\end{array}$ & $\begin{array}{l}\text { Close monitoring } \\
\text { (55) }\end{array}$ & 720 mg bid (93) \\
\hline
\end{tabular}

aeGFR 60-89 ml/min. beGFR 30-59 ml/min. ceGFR 15-29 ml/min. deGFR <15 ml/min. TKIs, tyrosine kinase inhibitors; NK, not known; qd, once daily; bid, twice daily; ESRD, end-stage renal disease; eGFR, estimated glomerular filtration rate; HD, hemodialysis.

Caution is recommended in patients with severe RI since there are no published PK data available for ceritinib treatment in this population (23).
Crizotinib. Patients with mild and moderate RI had a similar crizotinib exposure compared to patients with NRF (77). Similarly, a population PK analysis revealed that mild to 
moderate RI did not significantly affect the PK of crizotinib (78). Due to the small size of the increases in crizotinib exposure (5-15\%), dose adjustment is not required for patients with mild to moderate RI $(24,25,77,78)$. However, patients with severe RI exhibited increases in crizotinib AUC and $\mathrm{C}_{\max }$ of 79 and $34 \%$, respectively, compared to subjects with NRF (77). Thus, crizotinib at a dose of $250 \mathrm{mg}$ once daily is recommended for patients with severe RI $(24,25,77)$. A case report demonstrated that crizotinib $250 \mathrm{mg}$ once daily was tolerated and effective for a patient with ESRD not undergoing HD (79). In another case report, treatment with crizotinib $250 \mathrm{mg}$ once daily in a patient with ESRD undergoing HD was well-tolerated, without any significant adverse events (80).

Dabrafenib. Based on a patient population PK analysis, mild to moderate RI did not exert an effect on the concentrations of dabrafenib or its metabolites; therefore, dose adjustment is not required for patients with mild to moderate RI (27-29). The effect of severe RI on dabrafenib PK has not been established; therefore, dabrafenib should be administered with caution to patients with severe RI (28). A case report revealed that a patient with ESRD undergoing HD continued dabrafenib $75 \mathrm{mg}$ once daily and trametinib $0.5 \mathrm{mg}$ once daily for 9 months, and this dose was well-tolerated and effective for the patient (81).

Dacomitinib. Based on population PK analysis, patients with mild to moderate RI had comparable dacomitinib exposure to those with NRF, indicating that dose adjustment is not required in these patients $(30,31)$. The PK of dacomitinib has not been characterized in patients with severe RI; therefore, there are no dose adjustment recommendations for this patient group $(30,31)$.

Entrectinib. In a population PK analysis, no clinically significant differences in the PK of entrectinib were observed in patients with mild to moderate RI; therefore, dose adjustment is not required in patients with mild to moderate RI (33). Sufficient data for severe RI are currently lacking; therefore, dose recommendations cannot be made for these patients (33).

Erlotinib. Based on PK data, erlotinib was almost unaffected by RI; therefore, dose adjustment is not required in patients with mild to moderate RI $(35,37)$. A small study compared the PK of erlotinib and its active metabolite (OSI-420) in 3 patients with ESRD undergoing HD and 5 patients with NRF. Renal function and HD exerted only minor effects on the PK of erlotinib. No serious adverse events were reported in any of the cases, and 1 of the HD patients achieved partial response, indicating that dose adjustment is not required in patients with ESRD undergoing HD (82). A phase I and PK study was conducted to investigate the dose and PK of erlotinib in patients with HI or RI (37). The results demonstrated that patients with RI (creatinine 1.6-5.0 mg/dl) tolerated $150 \mathrm{mg}$ of erlotinib daily and appear to have a clearance similar to that of patients with NRF (37). In addition, a case report revealed that erlotinib was safe and effective for a patient with ESRD undergoing HD (83).

Gefitinib. RI is unlikely to significantly affect the PK of gefitinib, since $<4 \%$ of gefitinib and its metabolites are excreted by the kidney $(38,39)$. Therefore, the EMA recommended that dose adjustments are not required in patients with eGFR $>20 \mathrm{ml} / \mathrm{min} / 1.73 \mathrm{~m}^{2}$, but gefitinib should be administered with caution to patients with eGFR $\leq 20 \mathrm{ml} / \mathrm{min} 1.73 \mathrm{~m}^{2}$ (39). For patients with ESRD, several case reports revealed that gefitinib administered as $250 \mathrm{mg}$ once daily was safe and effective for patients with ESRD not on HD, or patients undergoing HD or peritoneal dialysis (84-88).

Larotrectinib. Following oral administration of a single 100-mg dose of larotrectinib to subjects with ESRD, the larotrectinib AUC increased by $46 \%$ and $\mathrm{C}_{\max }$ increased by $25 \%$ when compared to subjects with NRF $(41,42)$. Therefore, dose adjustment is not required for patients with RI of any severity $(41,42)$.

Lorlatinib. Based on population PK analysis, no clinically meaningful differences in lorlatinib PK were observed in patients with mild to moderate RI, suggesting that dose adjustment is not required in patients with mild to moderate RI $(43,44)$. The effect of severe RI on lorlatinib PK is unknown; therefore, use of lorlatinib in this patient population is not recommended (44).

Osimertinib. No clinical studies have been conducted to evaluate the effect of RI on the PK of osimertinib. Based on a population PK analysis, the osimertinib exposure was similar among patients with mild to severe RI and those with NRF $(45,46,89)$. Patients with ESRD have not been analyzed, but three case reports revealed that osimertinib at a dose of $80 \mathrm{mg}$ orally once daily was safe and effective for patients with ESRD undergoing HD (90-92). Based on these results, dose adjustment is not required for patients with mild to severe RI, or patients with ESRD undergoing HD (45,46,89-92).

Trametinib. A population PK analysis demonstrated that mild to moderate RI did not affect the PK of trametinib; therefore, dose adjustment is not required for these patient populations (48-50). As the effect of severe RI on the PK of trametinib is unknown, caution is suggested when trametinib is administered to patients with severe RI (49). In one case report, administration of dabrafenib $75 \mathrm{mg}$ once daily combined with trametinib $0.5 \mathrm{mg}$ once daily was well-tolerated and effective for a patient with ESRD undergoing HD (81).

Vandetanib. In a PK study, the $\mathrm{AUC}$ and $\mathrm{C}_{\max }$ of vandetanib increased by 46 and $7 \%, 62$ and $9 \%$, and 79 and $11 \%$ in patients with mild, moderate and severe RI, respectively, when compared to subjects with NRF (53). Clinical data suggested that dose adjustment is not required in patients with mild RI. The FDA and EMA recommendations differ in regards to patients with moderate to severe RI $(51,52)$. The FDA recommends reducing the vandetanib dose in these patients (51), whereas the EMA indicates that vandetanib is not recommended for these patients due to limited data availability (52).

Vemurafenib. In a population PK analysis, the clearance of vemurafenib in patients with mild to moderate RI was similar to that in patients with NRF (56), indicating that dose adjustment is not required for patients with mild to moderate 
Table V. Potential hepatotoxic and nephrotoxic effects of TKIs.

\begin{tabular}{|c|c|c|}
\hline TKIs (Refs.) & Hepatotoxicity & Nephrotoxicity \\
\hline fatinib $(10,11,98)$ & $\begin{array}{l}\text { Any grade: ALT elevation }(20.1-54 \%) \text {, } \\
\text { AST elevation }(15.1-46 \%) \text {, } \\
\text { ALP elevation }(34-51 \%) \text {, Bil elevation }(16 \%) \\
\text { Grade 3/4: ALT elevation (2\%), } \\
\text { AST elevation }(0.4-3 \%) \text {, ALP elevation }(2-3 \%) \text {, } \\
\text { Bil elevation (1\%) Fatal HI }(0.2 \%)\end{array}$ & $\begin{array}{l}\text { Any grade: Creatinine clearance decreased ( } 49 \% \\
\text { Grade } 3 / 4 \text { : Creatinine clearance decreased }(2 \%) \\
\text { Acute renal failure }(0.3 \%)\end{array}$ \\
\hline Alectinib $(12,13,99,100)$ & $\begin{array}{l}\text { Any grade: ALT elevation (14\%), } \\
\text { AST elevation ( } 15 \%) \text {, ALP elevation }(6.2 \%) \text {, } \\
\text { Bil elevation ( } 18 \%) \text { Grade } 3 / 4 \text { : } \\
\text { ALT elevation }(3.7 \%) \text {, AST elevation }(3.7 \%) \text {, } \\
\text { ALP elevation }(0.2 \%) \text {, Bil elevation }(3.2 \%)\end{array}$ & $\begin{array}{l}\text { Any grade: RI ( } 12 \%) \text {, creatinine increased }(7.2 \% \\
\text { AKI }(1 \%) \\
\text { Grade } 3 / 4: \text { RI }(3.9 \%) \text {, creatinine increased }(0.7 \% \\
\text { AKI }(1 \%)\end{array}$ \\
\hline Brigatinib $(15,16,101)$ & $\begin{array}{l}\text { Any grade: ALT elevation }(40 \%) \text {, } \\
\text { AST elevation }(65 \%) \text {, ALP elevation }(29 \%) \text {, } \\
\text { Bil elevation ( } 18 \%) \text { Grade } 3 / 4 \text { : } \\
\text { ALT elevation }(2.7 \%) \text {, AST elevation }(0 \%) \text {, } \\
\text { ALP elevation }(0.9 \%) \text {, Bil elevation }(3.2 \%)\end{array}$ & $\begin{array}{l}\text { Any grade: Creatinine increased }(2 \%) \\
\text { Grade 3/4: Creatinine increased }(0 \%)\end{array}$ \\
\hline Cabozantinib $(17-19,102)$ & $\begin{array}{l}\text { Any grade: ALT elevation ( } 86 \%) \text {, } \\
\text { AST elevation ( } 86 \%) \text {, ALP elevation }(52 \%) \text {, } \\
\text { Bil elevation (25\%) Grade } 3 / 4 \text { : } \\
\text { ALT elevation (6\%), AST elevation }(3 \%) \text {, } \\
\text { ALP elevation ( } 3 \%) \text {, Bil elevation }(2 \%)\end{array}$ & $\begin{array}{l}\text { Proteinuria }(1-10 \%) \text {, dysuria }(1-10 \%) \text {, } \\
\text { hematuria }(1-10 \%) \\
\text { Acute renal failure }(<1 \%)\end{array}$ \\
\hline Ceritinib $(22,23,103)$ & $\begin{array}{l}\text { Any grade: ALT elevation (80-91\%), } \\
\text { AST elevation }(75-86 \%) \text {, } \\
\text { ALP elevation }(81 \%) \text {, Bil elevation }(15 \%) \\
\text { Grade 3/4: ALT elevation (27-34\%), } \\
\text { AST elevation }(13-21 \%) \text {, ALP elevation }(12 \%) \text {, } \\
\text { Bil elevation }(0.5-1 \%)\end{array}$ & $\begin{array}{l}\text { Any grade: Creatinine increased }(22.1-77 \%) \\
\text { Grade } 3 / 4 \text { : Creatinine increased }(0.5-4.2 \%) \\
\text { Renal failure }(2 \%), \mathrm{RI}(1 \%)\end{array}$ \\
\hline Crizotinib $(24,25,101)$ & $\begin{array}{l}\text { Any grade: ALT elevation }(76-79 \%) \text {, } \\
\text { AST elevation }(61-66 \%) \text {, Bil elevation }(4.7 \%) \\
\text { Grade 3/4: ALT elevation (15-17\%), } \\
\text { AST elevation }(8-9 \%) \text {, Bil elevation }(0 \%) \\
\text { Fatal hepatotoxicity }(0.1 \%) \text {, } \\
\text { Hepatic failure }(1 \%)\end{array}$ & $\begin{array}{l}\text { Any grade: eGFR decreased }(76 \%) \text {, creatinine } \\
\text { increased }(8-23 \%) \\
\text { Grade } 3 / 4 \text { : eGFR decreased }(3.6 \%) \text {, creatinine } \\
\text { increased }(0.7-2 \%) \\
\text { Renal cysts }(3-5 \%) \text {, acute renal failure }(<1 \%) \text {, } \\
\text { renal failure }(<1 \%)\end{array}$ \\
\hline $\begin{array}{l}\text { Dabrafenib } \\
(27,28,104,105)\end{array}$ & $\begin{array}{l}\text { Any grade: ALT elevation ( } 48 \%) \text {, } \\
\text { AST elevation ( } 57 \%) \text {, ALP elevation }(38 \%) \\
\text { Grade 3/4: ALT elevation (5\%), }\end{array}$ & $\begin{array}{l}\text { Any grade: Creatinine increased }(21 \%) \text {, } \\
\text { Grade } 3 / 4 \text { : Creatinine increased }(1.1 \%) \\
\text { Renal failure }(<1 \%) \text {, }\end{array}$ \\
\hline
\end{tabular}

Dacomitinib $(30,31,106)$ Any grade: ALT elevation (40\%), AST elevation (35\%), ALP elevation (22\%), Bil elevation (16\%) Grade 3/4:

ALT elevation (1.4\%), AST elevation (0.5\%), ALP elevation (0.5\%), Bil elevation (0.5\%)

Entrectinib $(33,107)$ Any grade: ALT elevation (36\%), AST elevation (42\%), ALP elevation (25\%) Grade 3/4: ALT elevation (2.8\%), AST elevation (2.5\%), ALP elevation $(0.9 \%)$

Erlotinib $(34,35,108,109)$ Any grade: ALT/AST elevation $(35-45 \%)$ Grade 3/4: ALT/AST elevation (10-14\%) Hepatic failure, Hepatorenal syndrome

Gefitinib $(38,39,106,110)$ Any grade: ALT elevation (34-38\%\%), AST elevation (40-57\%), Bil elevation (22\%) Grade 3/4: ALT elevation (2.4-13\%), AST elevation (2-8\%), Bil elevation $(0.5 \%)$

Any grade: Creatinine increased (24\%) Grade 3/4: Creatinine increased $(0 \%)$

Any grade: Creatinine increased (73\%) Grade 3/4: Creatinine increased $(2.1 \%)$

Severe acute renal failure $(0.5 \%)$, renal disorders $(3.1 \%)$

Grade 3/4: Renal disorders (1.1\%)

Any grade: Creatinine increased (1.5-16\%)

Grade 3/4: Creatinine increased $(0.5 \%)$

AKI or nephrotic syndrome (few cases) 
Table V. Continued.

\begin{tabular}{|c|c|c|}
\hline TKIs (Refs.) & Hepatotoxicity & Nephrotoxicity \\
\hline Larotrectinib $(41,42,111)$ & $\begin{array}{l}\text { Any grade: ALT elevation ( } 45 \%) \text {, } \\
\text { AST elevation (45\%), ALP elevation }(30 \%) \\
\text { Grade 3/4: ALT elevation (3\%), } \\
\text { AST elevation (3\%), ALP elevation }(3 \%)\end{array}$ & $\begin{array}{l}\text { Any grade: Creatinine increased }(13 \%) \\
\text { Grade 3/4: Creatinine increased }(0 \%)\end{array}$ \\
\hline Lorlatinib $(43,44,112)$ & $\begin{array}{l}\text { Any grade: ALT elevation }(28 \%) \text {, } \\
\text { AST elevation ( } 37 \%) \text {, ALP elevation }(24 \%) \\
\text { Grade 3/4: ALT elevation }(2.1 \%) \text {, } \\
\text { AST elevation ( } 2.1) \text {, ALP elevation }(1 \%)\end{array}$ & Not reported \\
\hline Osimertinib $(45,46,113)$ & $\begin{array}{l}\text { Any grade: ALT elevation (6-21\%), } \\
\text { AST elevation }(5-22 \%) \text {, Bil elevation }(14 \%) \\
\text { Grade 3/4: ALT elevation }(0.7 \%) \text {, } \\
\text { ALT elevation }(1.1 \%) \text {, Bil elevation }(0 \%)\end{array}$ & $\begin{array}{l}\text { Any grade: Creatinine increased }(12.2 \%) \\
\text { Grade } 3 / 4: \text { Creatinine increased }(0 \%)\end{array}$ \\
\hline $\begin{array}{l}\text { Trametinib } \\
(48,49,104,105)\end{array}$ & $\begin{array}{l}\text { Any grade: ALT elevation ( } 39 \%) \text {, } \\
\text { AST elevation (60\%), ALP elevation }(24 \%) \\
\text { Grade 3/4: ALT elevation ( } 3 \%) \text {, } \\
\text { AST elevation ( } 2 \%) \text {, ALP elevation }(2 \%)\end{array}$ & $\begin{array}{l}\text { Any grade: Creatinine increased }(21 \%) \\
\text { Grade } 3 / 4 \text { : Creatinine increased }(1.1 \%)\end{array}$ \\
\hline Vandetanib $(51,52,114)$ & $\begin{array}{l}\text { Any grade: ALT elevation }(51 \%) \text {, } \\
\text { Bil elevation ( } 13 \%) \text { Grade } 3 / 4 \text { : } \\
\text { ALT elevation }(2 \%) \text {, Bil elevation }(0 \%)\end{array}$ & $\begin{array}{l}\text { Any grade: Creatinine increased }(16 \%) \\
\text { Grade } 3 / 4 \text { : Creatinine increased }(0 \%)\end{array}$ \\
\hline Vemurafenib $(54,55,115)$ & $\begin{array}{l}\text { Any grade: ALT elevation }(67 \%) \text {, } \\
\text { AST elevation ( } 71 \% \text { ), ALP elevation }(69 \%) \text {, } \\
\text { Bil elevation ( } 33 \%) \text { Grade } 3 / 4 \text { : } \\
\text { ALT elevation ( } 11 \%) \text {, AST elevation }(7 \%) \text {, } \\
\text { ALP elevation }(7 \%) \text {, Bil elevation }(2 \%)\end{array}$ & $\begin{array}{l}\text { Grade } 1 / 2 \text { : Creatinine increased }(26-86 \%) \\
\text { Grade } 3 / 4 \text { : Creatinine increased }(1.2-9.1 \%)\end{array}$ \\
\hline
\end{tabular}

TKIs, tyrosine kinase inhibitors; AST, aspartate aminotransferase; ALT, alanine aminotransferase; Bil, bilirubin; ALP, alkaline phosphatase; HI, hepatic impairment; RI, renal impairment; AKI, acute kidney injury; eGFR, estimated glomerular filtration rate.

RI (54-56). The effect of severe RI on vemurafenib PK is unknown; therefore; close monitoring is required when vemurafenib is administered to patients with severe RI (55). Based on one case report, administration of vemurafenib at a dose of $720 \mathrm{mg}$ twice daily was safe and effective for a patient with ESRD undergoing HD (93).

\section{Potential, hepatotoxicity and nephrotoxicity of TKIs}

Some TKIs may cause hepatic and renal toxicity $(94,95)$, with the most common hepatic toxicities induced by TKIs include increases in the hepatic alkaline phosphatase and Bil. The most common renal toxicities induced by TKIs included proteinuria (with increased serum creatinine), acute kidney injury, chronic kidney disease and renal failure (95). To reduce the risk of hepatic and renal side effects, the use of potentially hepatotoxic or nephrotoxic TKIs requires specific monitoring and, when available, specific prevention methods in patients who already have abnormal hepatic or renal function (94-96). The incidence, severity and pattern of hepatic and renal toxicities may differ among different TKIs. The present review summarized the potential hepatotoxicity and nephrotoxicity of 17 TKIs in order to provide information for clinicians and pharmacists when prescribing these drugs to patients with $\mathrm{HI}$ or RI. The potential hepatotoxic and nephrotoxic effects of TKIs are listed in Table V.
When patients do not exhibit HI and RI prior to TKI treatment but develop TKI-induced HI or RI, the dose modification schedule is based on the grade of the adverse events. For example, if patients experience grade 3 RI during alectinib treatment, the recommendation is to temporarily suspend alectinib until serum creatinine recovers to $\leq 1.5$ times the ULN, then resume at a reduced dose; alectinib should be permanently discontinued if patients experienced grade 4 RI during treatment.

\section{Discussion}

Current evidence suggests that severe RI or ESRD may significantly affect the PK of drugs that are primarily eliminated by the liver, whereas the effects are not significant for mild and moderate RI $(67,68,94)$. As shown in the present review, most TKIs are primarily eliminated via the liver, indicating that the effects of mild and moderate RI on the PK of most TKIs are not clinically relevant. It was herein demonstrated that, apart from vandetanib, dose adjustment is not required for the other 16 TKIs in patients with mild or moderate RI. However, for patients with severe RI or ESRD, it is recommended that TKIs be administered with caution and dose reductions be carefully established; otherwise, TKIs should not be used at all. 
Since most TKIs are eliminated by the liver, the effects of $\mathrm{HI}$ on the PK of TKIs may be more significant compared with the effects of RI $(8,58,97)$. According to the present review, 1 TKI (cabozantinib) requires dose reduction in patients with mild HI; 3 TKIs (crizotinib, larotrectinib, cabozantinib) require dose reduction and 2 TKIs (lorlatinib, vandetanib) are not recommended for use in patients with moderate $\mathrm{HI}$; 5 TKIs (crizotinib, ceritinib, alectinib, brigatinib, larotrectinib) require dose reduction and 11 TKIs are recommended to be used with caution or not at all, in patients with severe HI.

For certain TKIs (e.g., vandetanib), dose adjustment recommendations differ between the FDA and EMA $(51,52)$. In order to provide more data to help physicians decide on individual treatment options, and taking into consideration the regulatory laws of each country, both recommendations were included in this review. Moreover, a number of clinical trials have excluded patients with ESRD undergoing HD, and only a few case reports have reported the safety and efficiency of certain TKIs in patients with ESRD undergoing HD; those case reports were included in this review in order to provide more information on drug administration in patients ESRD undergoing HD.

As some TKIs can induce hepatic and renal toxicities, it is important to monitor hepatic and renal function in patients receiving potentially hepatotoxic or nephrotoxic drugs (98-115). If prescription of a hepatotoxic or nephrotoxic drug is necessary for patients with HI or RI, and there are no better tolerated alternatives, preventive methods, including hepatic and renal function monitoring, adverse reactions monitoring and appropriate dosage adjustment, should be considered.

To date, there are several methods available for selecting an appropriate dose in patients with HI or RI, such as physiologically based pharmacokinetics (PBPK) models, two-stage PK studies, and population PK studies $(50,56,116,117)$. However, the physiological bases of the alterations in the absorption, distribution, metabolism and excretion characteristics in patients with HI or RI have not been fully elucidated, and the PK of a drug may display high interindividual variability in patients with HI or RI. Therefore, dose recommendations cannot be made with a high level of granularity and precision (116). To overcome interindividual variability in PK and confirm the attainment of target concentrations, therapeutic drug monitoring may be the best option for patients with HI or RI, and should be considered early after initiation of therapy (118). In addition, close monitoring of potential adverse reactions is required for patients with HI or RI.

\section{Conclusion}

The PK profile of a drug for individuals with HI or RI may lead to either increased or decreased drug exposure, necessitating dose adjustment. However, the number of clinical trials that provide data from patients with $\mathrm{HI}$ or RI is scarce, particularly for patients with severe HI or RI, making it is difficult to select an appropriate TKI dosage. The aim of the present review was to aid clinicians by providing dose recommendations for 17 TKIs in patients with varying degrees of HI or RI. The described dose adjustment is a preventive method for reduce the risk of toxicities for patients who already have abnormal hepatic or renal function. When patients experience TKI-induced HI or RI, the dose modification schedule is based on the grade of adverse events.

\section{Acknowledgements}

Not applicable.

\section{Funding}

No funding was received.

\section{Availability of data and materials}

All data generated or analyzed during the present study are included in this published article.

\section{Authors' contributions}

DZ and JW designed the study and revised the manuscript. DZ, JC and XL performed the literature search. DZ drafted the manuscript. All the authors have read and approved the final version of this manuscript.

\section{Ethics approval and consent to participate}

Not applicable.

\section{Patient consent for publication}

Not applicable.

\section{Competing interests}

All the authors declare that they have no competing interests.

\section{References}

1. Ferlay J, Steliarova-Foucher E, Lortet-Tieulent J, Rosso S, Coebergh JW, Comber H, Forman D and Bray F: Cancer incidence and mortality patterns in Europe: Estimates for 40 countries in 2012. Eur J Cancer 49: 1374-403, 2013.

2. Gridelli C, Rossi A, Carbone DP, Guarize J, Karachaliou N, Mok T, Petrella F, Spaggiari L and Rosell R: Non-small-cell lung cancer. Nat Rev Dis Primers 1: 15009, 2015.

3. Sgambato A, Casaluce F, Maione P and Gridelli C: Targeted therapies in non-small cell lung cancer: A focus on ALK/ROS1 tyrosine kinase inhibitors. Expert Rev Anticancer Ther 18: 71-80, 2018.

4. Lee DH: Treatments for EGFR-mutant non-small cell lung cancer (NSCLC): The road to a success, paved with failures. Pharmacol Ther 174: 1-21, 2017.

5. Ettinger DS, Wood DE, Aggarwal C, Aisner DL, Akerley W, Bauman JR, Bharat A, Bruno DS, Chang JY, Chirieac LR, et al: NCCN guidelines insights: Non-small cell lung cancer, version 1.2020. J Natl Compr Canc Netw 17: 1464-1472, 2019.

6. Planchard D, Popat S, Kerr K, Novello S, Smit EF, Faivre-Finn C, Mok TS, Reck M, Van Schil PE, Hellmann MD, et al: Metastatic non-small cell lung cancer: ESMO clinical practice guidelines for diagnosis, treatment and follow-up. Ann Oncol 29 (Suppl 4): iv192-iv237, 2018.

7. Holleman MS, van Tinteren H, Groen HJ, Al MJ and Uyl-de Groot CA: First-line Tyrosine Kinase inhibitors in EGFR mutation-positive non-small-cell lung cancer: A network meta-analysis. Onco Targets Ther 12: 1413-1421, 2019. 
8. Verbeeck RK: Pharmacokinetics and dosage adjustment in patients with hepatic dysfunction. Eur J Clin Pharmacol 64: 1147-1161, 2008.

9. Verbeeck RK and Musuamba FT: Pharmacokinetics and dosage adjustment in patients with renal dysfunction. Eur J Clin Pharmacol 65: 757-773, 2009.

10. US Food and Drug Administration. Label. Available from: https://www.accessdata.fda.gov/drugsatfda docs/label/2019/ 201292s015lbl.pdf. Accessed Feb 2, 2020.

11. European Medicines Agency. Product information. Available from: https://www.ema.europa.eu/en/documents/product-information/giotrif-epar-product-information_en.pdf. Accessed Feb 2, 2020

12. US Food and Drug Administration. Label. Available from: https://www.accessdata.fda.gov/drugsatfda_docs/label/2018/ 208434s004lbl.pdf. Accessed Feb 2, 2020.

13. European Medicines Agency. Product information. Available from: https://www.ema.europa.eu/en/documents/product-information/alecensa-epar-product-information_en.pdf. Accessed Feb 2, 2020.

14. Morcos PN, Cleary Y, Sturm-Pellanda C, Guerini E, Abt M, Donzelli M, Vazvaei F, Balas B, Parrott N and Yu L: Effect of hepatic impairment on the pharmacokinetics of alectinib. J Clin Pharmacol 58: 1618-1628, 2018.

15. US Food and Drug Administration. Label. Available from: https://www.accessdata.fda.gov/drugsatfda_docs/label/2018/ 208772s004lbl.pdf. Accessed Feb 2, 2020.

16. European Medicines Agency. Product information. Available from: https://www.ema.europa.eu/en/documents/product-information/alunbrig-epar-product-information_en.pdf. Accessed Feb 2, 2020.

17. US Food and Drug Administration. Label. Available from: https://www.accessdata.fda.gov/drugsatfda_docs/label/2020/ 203756s008lbl.pdf. Accessed Feb 2, 2020.

18. US Food and Drug Administration. Label. Available from: https://www.accessdata.fda.gov/drugsatfda_docs/label/2020/ 208692s007lbl.pdf. Accessed Feb 2, 2020.

19. European Medicines Agency. Product information. Available from: https://www.ema.europa.eu/en/documents/product-information/cometriq-epar-product-information_en-0.pdf. Accessed Feb 2, 2020

20. Nguyen L, Chapel S, Tran BD and Lacy S: Updated population pharmacokinetic model of cabozantinib integrating various cancer types including hepatocellular carcinoma. J Clin Pharmacol 59: 1551-1561, 2019.

21. Nguyen L, Holland J, Ramies D, Mamelok R, Benrimoh N, Ciric S, Marbury T, Preston RA, Heuman DM, Gavis E and Lacy S: Effect of renal and hepatic impairment on the pharmacokinetics of cabozantinib. J Clin Pharmacol 56: 1130-1140, 2016.

22. US Food and Drug Administration. Label. Available from: https://www.accessdata.fda.gov/drugsatfda_docs/label/2019/ 205755s016lbl.pdf. Accessed Feb 2, 2020.

23. European Medicines Agency. Product Information. Available from: https://www.ema.europa.eu/en/documents/product-information/zykadia-epar-product-information_en.pdf. Accessed Feb 2, 2020

24. US Food and Drug Administration. Label. Available from: https://www.accessdata.fda.gov/drugsatfda_docs/label/2011/ 202570s000lbl.pdf. Accessed Feb 2, 2020.

25. European Medicines Agency. Product Information. Available from: https://www.ema.europa.eu/en/documents/product-information/xalkori-epar-product-information_en.pdf. Accessed Feb 2, 2020

26. El-Khoueiry AB, Sarantopoulos J, O'Bryant CL, Ciombor KK, Xu H, O'Gorman M, Chakrabarti J, Usari T and El-Rayes BF: Evaluation of hepatic impairment on pharmacokinetics and safety of crizotinib in patients with advanced cancer. Cancer Chemother Pharmacol 81: 659-670, 2018.

27. US Food and Drug Administration. Label. Available from: https://www.accessdata.fda.gov/drugsatfda_docs/label/2020/ 202806s015lbl.pdf. Accessed Feb 2, 2020.

28. European Medicines Agency. Product information. Available from: https://www.ema.europa.eu/en/documents/product-information/tafinlar-epar-product-information_en.pdf. Accessed Feb 2, 2020.

29. Ouellet D, Gibiansky E, Leonowens C, O'Hagan A, Haney P, Switzky J and Goodman VL: Population pharmacokinetics of dabrafenib, a BRAF inhibitor: Effect of dose, time, covariates, and relationship with its metabolites. J Clin Pharmacol 54: 696-706, 2014.
30. US Food and Drug Administration. Label. Available from: https://www.accessdata.fda.gov/drugsatfda_docs/label/2018/ 211288s000lbl.pdf. Accessed Feb 2, 2020.

31. European Medicines Agency. Product information. Available from: https://www.ema.europa.eu/en/documents/product-information/vizimpro-epar-product-information_en.pdf. Accessed Feb 2, 2020.

32. Giri N, Masters JC, Plotka A, Liang Y, Boutros T, Pardo P, O'Connell $\mathrm{J}$ and Bello $\mathrm{C}$ : Investigation of the impact of hepatic impairment on the pharmacokinetics of dacomitinib. Invest New Drugs 33: 931-941, 2015.

33. US Food and Drug Administration. Label. Available from: https://www.accessdata.fda.gov/drugsatfda_docs/label/2019/ 212725s000lbl.pdf. Accessed May 3, 2020.

34. US Food and Drug Administration. Label. Available from: https://www.accessdata.fda.gov/drugsatfda_docs/label/2016/ 021743s025lbl.pdf. Accessed Feb 2, 2020.

35. European Medicines Agency. Product information. Available from: https://www.ema.europa.eu/en/documents/product-information/tarceva-epar-product-information_en.pdf. Accessed Feb 2, 2020.

36. O'Bryant CL, Haluska P, Rosen L, Ramanathan RK, Venugopal B, Leong S, Boinpally R, Franke A, Witt K, Evans J, et al: An open-label study to describe pharmacokinetic parameters of erlotinib in patients with advanced solid tumors with adequate and moderately impaired hepatic function. Cancer Chemother Pharmacol 69: 605-612, 2012.

37. Miller AA, Murry DJ, Owzar K, Hollis DR, Lewis LD, Kindler HL, Marshall JL, Villalona-Calero MA, Edelman MJ, Hohl RJ, et al: Phase I and pharmacokinetic study of erlotinib for solid tumors in patients with hepatic or renal dysfunction: CALGB 60101. J Clin Oncol 25: 3055-3060, 2007.

38. US Food and Drug Administration. Label. Available from: https://www.accessdata.fda.gov/drugsatfda_docs/label/2005/ 021399s008lbl.pdf. Accessed Feb 2, 2020.

39. European Medicines Agency. Product information. Available from: https://www.ema.europa.eu/en/documents/product-information/gefitinib-mylan-epar-product-information_en.pdf. Accessed Feb 2, 2020.

40. Horak J, White J, Harris AL, Verrill M, Carmichael J, Holt A, Cantarini M, Macpherson M, Swaisland A, Swaisland H and Twelves C: The effect of different etiologies of hepatic impairment on the pharmacokinetics of gefitinib. Cancer Chemother Pharmacol 68: 1485-1495, 2011.

41. US Food and Drug Administration. Label. Available from: https://www.accessdata.fda.gov/drugsatfda_docs/label/2018/ 210861s000lbl.pdf. Accessed Feb 2, 2020.

42. European Medicines Agency. Product information. Available from: https://www.ema.europa.eu/en/documents/product-information/vitrakvi-epar-product-information_en.pdf. Accessed Feb 2, 2020.

43. US Food and Drug Administration. Label. Available from: https://www.accessdata.fda.gov/drugsatfda_docs/label/2018/ 210868s000lbl.pdf. Accessed Feb 2, 2020.

44. European Medicines Agency. Product information. Available from: https://www.ema.europa.eu/en/documents/product-information/lorviqua-epar-product-information_en.pdf. Accessed Feb 2, 2020.

45. US Food and Drug Administration. Label. Available from: https://www.accessdata.fda.gov/drugsatfda_docs/label/2019/ 208065s013lbl.pdf. Accessed Feb 2, 2020.

46. European Medicines Agency. Product information. Available from: https://www.ema.europa.eu/en/documents/product-information/tagrisso-epar-product-information_en.pdf. Accessed Feb 2, 2020.

47. Grande E, Harvey RD, You B, Batlle JF, Galbraith H, Sarantopoulos J, Ramalingam SS, Mann H, So K, Johnson M and Vishwanathan K: Pharmacokinetic study of osimertinib in cancer patients with mild or moderate hepatic impairment. J Pharmacol Exp Ther 369: 291-299, 2019.

48. US Food and Drug Administration. Label. Available from: https://www.accessdata.fda.gov/drugsatfda_docs/label/2020/ 204114s014lbl.pdf. Accessed Feb 2, 2020

49. European Medicines Agency. Product information. Available from: https://www.ema.europa.eu/en/documents/product-information/mekinist-epar-product-information_en.pdf. Accessed Feb 2, 2020.

50. Ouellet D, Kassir N, Chiu J, Mouksassi MS, Leonowens C, Cox D, DeMarini DJ, Gardner O, Crist W and Patel K: Population pharmacokinetics and exposure-response of trametinib, a MEK inhibitor, in patients with BRAF V600 mutation-positive melanoma. Cancer Chemother Pharmacol 77: 807-817, 2016. 
51. US Food and Drug Administration. Label. Available from: https://www.accessdata.fda.gov/drugsatfda_docs/label/2018/ 022405s014lbl.pdf. Accessed Feb 2, 2020.

52. European Medicines Agency. Product information. Available from: https://www.ema.europa.eu/en/documents/product-information/caprelsa-epar-product-information_en.pdf. Accessed Feb 2, 2020.

53. Weil A, Martin P, Smith R, Oliver S, Langmuir P, Read J and Molz KH: Pharmacokinetics of vandetanib in subjects with renal or hepatic impairment. Clin Pharmacokinet 49: 607-618, 2010.

54. US Food and Drug Administration. Label. Available from: https://www.accessdata.fda.gov/drugsatfda_docs/label/2017/ 202429s016lbl.pdf. Accessed Feb 22020.

55. European Medicines Agency. Product information. Available from: https://www.ema.europa.eu/en/documents/product-information/zelboraf-epar-product-information_en.pdf. Accessed Feb 2, 2020.

56. Zhang W, Heinzmann D and Grippo JF: Clinical pharmacokinetics of vemurafenib. Clin Pharmacokinet 56: 1033-1043, 2017.

57. Field KM and Michael M: Part II: Liver function in oncology: Towards safer chemotherapy use. Lancet Oncol 9: 1181-1190, 2008.

58. Krens SD, Lassche G, Jansman FG, Desar IM, Lankheet NA, Burger DM, van Herpen CM and van Erp NP: Dose recommendations for anticancer drugs in patients with renal or hepatic impairment. Lancet Oncol 20: e200-e207, 2019.

59. Pond SM and Tozer TN: First-pass elimination: Basic concept and clinical consequences. Clin Pharmacokinet 9: 1-25, 1984.

60. Chtioui $\mathrm{H}$ and Buclin T: Pharmacokinetics in hepatic impairment: Mind the protein binding. J Hepatol 63: 1539-1540, 2015.

61. Villeneuve JP and Pichette V: Cytochrome P450 and liver diseases. Curr Drug Metab 5: 273-282, 2004.

62. Zollner G, Fickert P, Silbert D, Fuchsbichler A, Marschall HU, Zatloukal K, Denk H and Trauner M: Adaptive changes in hepatobiliary transporter expression in primary biliary cirrhosis. J Hepatol 38: 717-727, 2003.

63. Proulx NL, Akbari A, Garg AX, Rostom A, Jaffey J and Clark HD: Measured creatinine clearance from timed urine collections substantially overestimates glomerular filtration rate in patients with liver cirrhosis: A Systematic review and individual patient Meta-analysis. Nephrol Dial Transplant 20: 1617-1622, 2005.

64. European Medicines Agency. Guideline on the evalution of the pharmacokinetics of medicinal products in patients with impaired hepatic function. https://www.ema.europa.eu/documents/ scientific-guideline/guideline-evaluation-pharmacokineticsmedicinal-products-patients-impaired-hepatic-function_en.pdf. Accessed Jan 202020.

65. US Food and Drug Administration. Guidance for industry: Pharmacokinetics in patients with impaired hepatic function: Study design, data analysis, and impact on dosing and labeling. https://www.fda.gov/downloads/drugs/guidance compliance regulatory information/guidances/ucm072123. pdf. Accessed Jan 202020

66. Mansfield AS, Rudek MA, Vulih D, Smith GL, Harris PJ and Ivy SP; NCI Organ Dysfunction Working Group: The effect of hepatic impairment on outcomes in phase I clinical trials in cancer subjects. Clin Cancer Res 22: 5472-5479, 2016.

67. Fujita K, Matsumoto N, Ishida H, Kubota Y, Iwai S, Shibanuma M and Kato Yo: Decreased disposition of anticancer drugs predominantly eliminated via the liver in patients with renal failure. Curr Drug Metab 20: 361-376, 2019.

68. Kim AH, Yoon S, Lee Y, Lee J, Bae E, Lee H, Kim DK, Lee S, Yu KS, Jang IJ and Cho JY: Assessment of Hepatic Cytochrome P450 3A activity using metabolic markers in patients with renal impairment. J Korean Med Sci 33: e298, 2018.

69. Matzke GR, Dowling TC, Marks SA and Murphy JE: Influence of kidney disease on drug disposition: An assessment of industry studies submitted to the FDA for new chemical entities 1999-2010. J Clin Pharmacol 56: 390-398, 2016.

70. Wiebe S, Schnell D, Külzer R, Gansser D, Weber A, Wallenstein G Halabi A, Conrad A and Wind S: Influence of renal impairment on the pharmacokinetics of afatinib: An Open-Label, Single-Dose Study. Eur J Drug Metab Pharmacokinet 42: 461-469, 2017.

71. Inker LA, Astor BC, Fox CH, Isakova T, Lash JP, Peralta CA, Kurella Tamura $\mathrm{M}$ and Feldman HI: KDOQI US commentary on the 2012 KDIGO clinical practice guideline for the evaluation and management of CKD. Am J Kidney Dis 63: 713-735, 2014.

72. Shah RR and Shah DR: Safety and tolerability of epidermal growth factor receptor (EGFR) tyrosine kinase inhibitors in oncology. Drug Saf 42: 181-198, 2019.
73. Imai H,Kaira K, Naruse I, Hayashi H, Iihara H, Kita Y,Mizusaki N, Asao T, Itoh Y, Sugiyama T, et al: Successful afatinib treatment of advanced non-small-cell lung cancer patients undergoing hemodialysis. Cancer Chemother Pharmacol 79: 209-213, 2017.

74. Bersanelli M, Tiseo M, Artioli F, Lucchi L and Ardizzoni A: Gefitinib and Afatinib treatment in an advanced Non-small cell lung cancer (NSCLC) Patient Undergoing Hemodialysis. Anticancer Res 34: 3185-3188, 2014.

75. Suzuki S, Haratani K, Takahama T, Watanabe S, Takegawa N, Hayashi H, Takeda M, Yonesaka K and Nakagawa K: Safety and Efficacy of alectinib in a patient with advanced NSCLC Undergoing Hemodialysis. J Thorac Oncol 14: e50-e52, 2019.

76. Hong Y, Passos VQ, Huang PH and Lau YY: Population pharmacokinetics of ceritinib in adult patients with tumors characterized by genetic abnormalities in anaplastic lymphoma kinase. J Clin Pharmacol 57: 652-662, 2017.

77. Tan W, Yamazaki S, Johnson TR, Wang R, O'Gorman MT, Kirkovsky L, Boutros T, Brega NM and Bello A: Effects of renal function on crizotinib pharmacokinetics: Dose recommendations for patients with ALK-Positive Non-Small cell lung cancer. Clin Drug Investig 37: 363-373, 2017.

78. Wang E, Nickens DJ, Bello A, Khosravan R, Amantea M, Wilner KD, Parivar K and Tan W: Clinical implications of the pharmacokinetics of crizotinib in populations of patients with non-small cell lung cancer. Clin Cancer Res 22: 5722-5728, 2016.

79. Kothari S, Ud-Din N, Lisi M and Coyle T: Crizotinib in anaplastic lymphoma kinasepositive anaplastic large cell lymphoma in the setting of renal insufficiency: A case report. J Med Case Rep 10: 176,2016

80. Song SH, Ryu JW, Jwa HY, Ha CW, Kim H, Jo JM and Han SH: ALK-positive lung cancer diagnosed with abdominal lymph nodes in a patient receiving hemodialysis. Thorac Cancer 10: 2188-2191, 2019

81. Park JJ, Boddy AV, Liu X, Harris D, Lee V, Kefford RF and Carlino MS: Pharmacokinetics of dabrafenib in a patient with metastatic melanoma undergoing haemodialysis. Pigment Cell Melanoma Res 30: 68-71, 2017.

82. Togashi Y, Masago K, Fukudo M, Terada T, Ikemi Y, Kim YH, Fujita S, Irisa K, Sakamori Y, Mio T, et al: Pharmacokinetics of Erlotinib and its active metabolite OSI-420 in patients with non-small cell lung cancer and chronic renal failure who are undergoing hemodialysis. J Thorac Oncol 5: 601-605, 2010.

83. Gridelli C, Maione P, Galetta D and Rossi A: Safety profile of Erlotinib in patients with advanced non-small cell lung cancer with chronic renal failure. J Thorac Oncol 2: 96-98, 2007

84. Rossi A, Maione P, Del Gaizo F, Guerriero C, Castaldo V and Gridelli C: Safety profile of gefitinib in advanced non-small cell lung cancer elderly patients with chronic renal failure: Two clinical cases. Lung Cancer 47: 421-423, 2005.

85. Yamaguchi $T$, Isogai $S$, Okamura T, Uozu S, Mieno $Y$, Hoshino T, Goto Y, Hayashi M, Nakanishi T and Imaizumi K: Pharmacokinetics of Gefitinib in a patient with non-small cell lung cancer undergoing continuous ambulatory peritoneal dialysis. Case Rep Oncol 8: 78-82, 2015.

86. Luo J, Ni L, Wang M, Zhong W, Xiao Y, Zheng K and Hu P Pharmacokinetic analysis of gefitinib in a patient with advanced non-small cell lung cancer undergoing hemodialysis. Thorac Cancer 7: 251-253, 2016.

87. Shinagawa N, Yamazaki K, Asahina H, Agata J, Itoh T and Nishimura M: Gefitinib administration in a patient with lung cancer undergoing hemodialysis. Lung Cancer 58: 422-424, 2007.

88. Del Conte A, Minatel E, Schinella D, Baresic T, Basso SM and Lumachi F: Complete metabolic remission with gefitinib in a hemodialysis patient with bone metastases from non-small cell lung cancer. Anticancer Res 34: 319-322, 2014

89. Yamada H, Satoh H, Hida N, Nakaizumi T, Terashima $H$ and Hizawa N: Osimertinib for an older de novo T790M patient with chronic kidney disease. Geriatr Gerontol Int 18: 503-504, 2018.

90. Tamura T, Takagi Y, Okubo H, Yamaguchi S, Kikkawa Y, Hashimoto I, Kaburagi T, Miura M, Satoh H and Hizawa N: Plasma concentration of osimertinib in a non-small cell lung cancer patient with chronic renal failure undergoing hemodialysis. Lung Cancer 112: 225-226, 2017.

91. Iwafuchi Y, Saito I and Narita I: Efficacy and safety of osimertinib in a hemodialysis patient with advanced non-small cell lung cancer. Ther Apher Dial 21: 416-417, 2017.

92. Matsunashi A, Fujimoto D, Hosoya K, Irie K, Fukushima S and Tomii K: Osimertinib in a patient with non-small cell lung cancer and renal failure undergoing hemodialysis: a case report. Invest New Drugs 38: 1192-1195, 2020. 
93. Iddawela M, Crook S, George L, Lakkaraju A, Nanayakkara N, Hunt R and Adam WR: Safety and efficacy of Vemurafenib in end stage renal failure. BMC Cancer 13: 581, 2013.

94. Porta C, Cosmai L, Gallieni M, Pedrazzoli P and Malberti F: Renal effects of targeted anticancer therapies. Nat Rev Nephrol 11: 354-370, 2015.

95. Qian J, Zhang X, Zhang B, Yan B, Wang L, Gu P, Wang W, Wang $\mathrm{H}$ and Han B: Tyrosine kinase inhibitor-related hepatotoxicity in patients with advanced lung adenocarcinoma: A real-world retrospective study. Cancer Manag Res 12: 3293-3299, 2020.

96. Jhaveri KD, Wanchoo R, Sakhiya V, Ross DW and Fishbane SL Adverse renal effects of novel molecular oncologic targeted therapies: A narrative review. Kidney Int Rep 2: 108-123, 2016.

97. GonzálezJ,Quiroga M,Escudero-Vilaplana V,Collado-Borrell R, Herranz-Alonso A and Sanjurjo Sáez M: Posology adjustments of oral antineoplastic agents for special populations: Patients with renal impairment, hepatic impairment and hematologic toxicities. Expert Opin Drug Saf 17: 553-572, 2018.

98. Park K, Tan EH, O'Byrne K, Zhang L, Boyer M, Mok T, Hirsh V, Yang JC, Lee KH, Lu S, et al: Afatinib versus gefitinib as first-line treatment of patients with EGFR mutation-positive non-small-cell lung cancer (LUX-Lung 7): A phase 2B, open-label, randomised controlled trial. Lancet Oncol 17: 577-589, 2016

99. Camidge DR,Dziadziuszko R,Peters S,MokT,Noe J,NowickaM Gadgeel SM, Cheema P, Pavlakis N, de Marinis F, et al: Updated efficacy and safety data and impact of the EML4-ALK fusion variant on the efficacy of Alectinib in untreated Alk-positive advanced non-small cell lung cancer in the global phase III ALEX Study. J Thorac Oncol 14: 1233-1243, 2019.

100. Zhu V and Ou SH: Safety of alectinib for the treatment of metastatic ALK-rearranged non-small cell lung cancer. Expert Opin Drug Saf 16: 509-514, 2017.

101. Camidge DR, Kim HR, Ahn MJ, Yang JC, Han JY, Lee JS, Hochmair MJ, Li JY, Chang GC, Lee KH, et al: Brigatinib versus Crizotinib in ALK-positive Non-small-cell lung cancer. N Engl J Med 379: 2027-2039, 2018.

102. Choueiri TK, Halabi S, Sanford BL, Hahn O, Michaelson MD, Walsh MK, Feldman DR, Olencki T, Picus J, Small EJ, et al Cabozantinib versus Sunitinib as initial targeted therapy for patients with metastatic renal cell carcinoma of poor or intermediate risk: The alliance A031203 CABOSUN trial. J Clin Oncol 35: 591-597, 2017

103. Kim DW, Mehra R, Tan DSW, Felip E, Chow LQM, Camidge DR, Vansteenkiste J, Sharma S, De Pas T, Riely GJ, et al: Intracrania and whole-body response of ceritinib in ALK inhibitor-naïve and previously ALK inhibitor-treated patients with ALK-rearranged non-small-cell lung cancer (NSCLC): Updated results from the phase 1, multicentre, open-label ASCEND-1 trial. Lancet Oncol 17: 452-463, 2016

104. Knispel S, Zimmer L, Kanaki T, Ugurel S, Schadendorf D and Livingstone E: The safety and efficacy of dabrafenib and trametinib for the treatment of melanoma. Expert Opin Drug Saf 17: 73-87, 2018

105. Planchard D, Smit EF, Groen HJM, Mazieres J, Besse B, Helland $\AA$, Giannone V, D'Amelio AM Jr, Zhang P, Mookerjee B and Johnson BE: Dabrafenib plus trametinib in patients with previously untreated $\mathrm{BRAF}^{\mathrm{V} 600 \mathrm{E}}$-mutant metastatic non-small-cell lung cancer: An open-label, phase 2 trial. Lancet Oncol 18: 1307-1316, 2017.
106. Wu YL, Cheng Y,Zhou X, Lee KH, Nakagawa K, Niho S, Tsuji F, Linke R, Rosell R, Corral J, et al: Dacomitinib versus gefitinib as first-line treatment for patients with EGFR-mutation-positive non-small-cell lung cancer (ARCHER 1050): A randomised, open-label, phase 3 trial. Lancet Oncol 18: 1454-1466, 2017.

107. Doebele RC, Drilon A, Paz-Ares L, Siena S, Shaw AT, Farago AF, Blakely CM, Seto T, Cho BC, Tosi D, et al: Entrectinib in patients with advanced or metastatic NTRK fusionpositive solid tumours: Integrated analysis of three phase 1-2 trials. Lancet Oncol 21: 271-282, 2020.

108. Choi HD and Chang MJ: Eye, hepatobiliary, and renal disorders of erlotinib in patients with non-small-cell lung cancer: A meta-analysis. PLoS One 15: e0234818, 2020.

109. Schacher-Kaufmann S and Pless M: Acute fatal liver toxicity under Erlotinib. Case Rep Oncol 3: 182-188, 2010.

110. Hsiue EH, Lee JH, Lin CC and Yang JC: Safety of gefitinib in non-small cell lung cancer treatment. Expert Opin Drug Saf 15: 993-1000, 2016.

111. Laetsch TW, DuBois SG, Mascarenhas L, Turpin B, Federman N, Albert CM, Nagasubramanian R, Davis JL, Rudzinski E, Feraco AM, et al: Larotrectinib for paediatric solid tumours harbouring NTRK gene fusions: Phase 1 results from a multicentre, open-label, phase 1/2 study. Lancet Oncol 19: 705-714, 2018

112. Shaw AT, Solomon BJ, Chiari R, Riely GJ, Besse B, Soo RA, Kao S, Lin CC, Bauer TM, Clancy JS, et al: Lorlatinib in advanced ROS1-positive non-small-cell lung cancer: A multicentre, open-label, single-arm, phase 1-2 trial. Lancet Oncol 20: 1691-1701, 2019

113. Cao Y, Qiu X, Xiao G, Hu H and Lin T: Effectiveness and safety of osimertinib in patients with metastatic EGFR T790M-positive NSCLC: An observational real-world study. PLoS One 14: e0221575, 2019.

114. Tsang VH, Robinson BG and Learoyd DL: The safety of vandetanib for the treatment of thyroid cancer. Expert Opin Drug Saf 15: 1107-1113, 2016.

115. Brose MS, Cabanillas ME, Cohen EE, Wirth LJ, Riehl T, Yue H, Sherman SI and Sherman EJ: Vemurafenib in patients with BRAF(V600E)-positive metastatic or unresectable papillary thyroid cancer refractory to radioactive iodine: A non-randomised, multicentre, open-label, phase 2 trial. Lancet Onco 17: 1272-1282, 2016.

116. Borella E, Poggesi I and Magni P: Prediction of the effect of renal impairment on the pharmacokinetics of new drugs. Clin Pharmacokinet 57: 505-514, 2018.

117. Hsueh $\mathrm{CH}$, Hsu V, Zhao P, Zhang L, Giacomini KM and Huang SM: PBPK modeling of the effect of reduced kidney function on the pharmacokinetics of drugs excreted renally by organic anion transporters. Clin Pharmacol Ther 103: 485-492, 2018.

118. Solassol I, Pinguet F and Quantin X: FDA- and EMA-approved tyrosine kinase inhibitors in advanced EGFR-mutated non-small cell lung cancer: Safety, tolerability, plasma concentration monitoring, and management. Biomolecules 9: 668, 2019.

This work is licensed under a Creative Commons Attribution-NonCommercial-NoDerivatives 4.0 International (CC BY-NC-ND 4.0) License. 